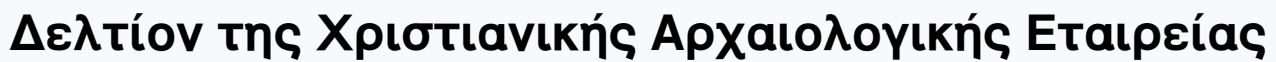

Tó 17 (1994)

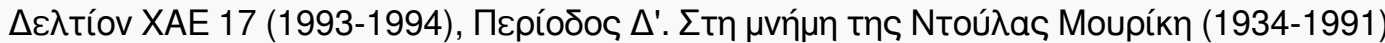

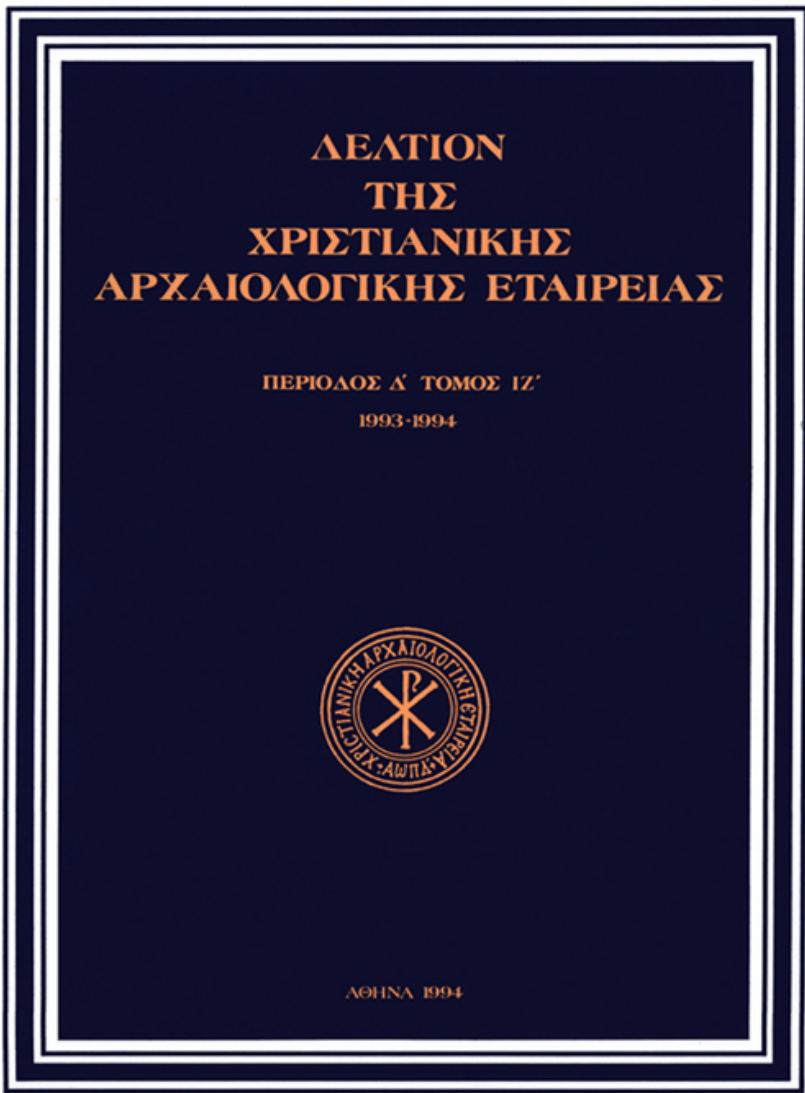

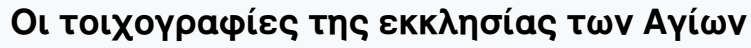

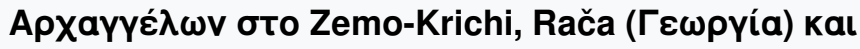

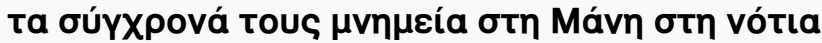

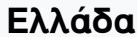

Efthalia C. CONSTANTINIDES

doi: $\underline{10.12681 / \text { dchae. } 1103}$

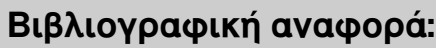

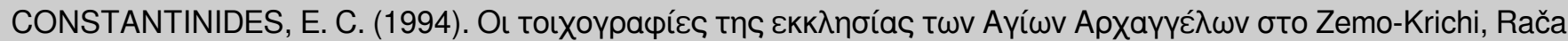

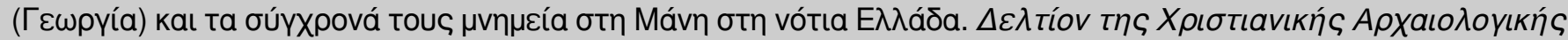
Eтaısías, 17, 181-192. https://doi.org/10.12681/dchae.1103 


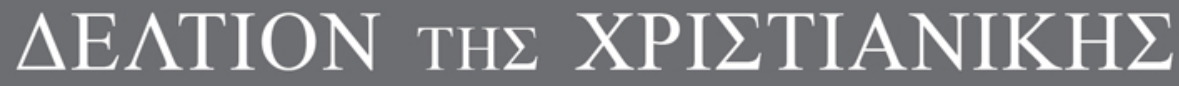 APXAIO $\Lambda$ OГIKH $\Sigma$ ETAIPEIA $\Sigma$}

The Frescoes of the Church of the Holy Archangels at

Zemo-Krichi, Rača (Georgia) and the Contemporary Monuments on Mani in Southern Greece

Efthalia CONSTANTINIDES

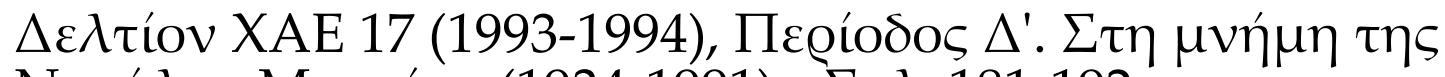

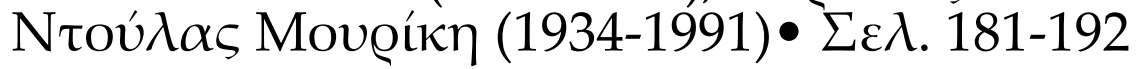

A@HNA 1994 
Efthalia C. Constantinides

\section{THE FRESCOES OF THE CHURCH OF THE HOLY ARCHANGELS AT ZEMO-KRICHI, RAČA (GEORGIA) AND THE CONTEMPORARY MONUMENTS ON MANI IN SOUTHERN GREECE}

$\mathrm{T}$ he destruction through the centuries of countless medieval Christian monuments in eastern Europe and Asia Minor has enhanced the study of Georgian monumental decorations leading to a more comprehensive view of the diffusion of Byzantine art from the tenth to the fifteenth century ${ }^{1}$. The continual dissemination of Constantinopolitan workmanship to cultural centers within Byzantium, Georgia and other neighbouring states served to aquaint the native artists of these regions with contemporary developments which in Georgia were often also adjoined to early art forms of Palestinian origin.

The single aisled basilican church of the Holy Archangels, situated in the cemetery of the village of ZemoKrichi in the province of Rača bordering upon the Caucasian mountains belongs to this latter category.

Three years heretofore this important medieval monument of the late tenth century suffered irreparable damage during a violent earthquake. Doula Mouriki and I had visited the church of the Holy Archangels during our stay in Georgia in 1980, and the present article constitutes the topic of a paper read at the 4th International Georgian Art-Historical Congress in Tbilisi (1983).

Professor Vakhtang Tsintsadze who studied the architecture and sculpture of the church of the Holy Archangels indentified it as an architectural form typical of the region of Rača as well as of the neighbouring province of Svaneti (Fig. 1) $)^{2}$. Its south portico (Fig. 2) was established as being a later addition, constructed during the second quarter of the eleventh century. It is in this period that the entire mural decoration is said to have been executed. This dating was also sustained by the discovery of an earlier painted layer of graphic decoration which had been applied only to the walls of the sanctuary. The mural painting of the church of the Holy Archangels was examined by Mrs. Tina Virsaládze and first published in 1963. The author dated the extant frescoes to the second quarter of the eleventh century on the basis of the iconography and style, and the magiscule lettering of the inscriptions ${ }^{3}$.

Mrs. Virsaládze detected that some of the eleventh-century frescoes at Zemo-Krichi had been restored at an early date, as for example the archangel Michael in the sanctuary (Fig. 3), parts of the Donors' figures (Fig. 4) and a section of St. John's himation in the Crucifixion scene. This was attributed by her to a local painter whose name, Choubinadzé, is partially preserved in a lengthy inscription written in minuscule letters. This later paleography was indentified by Mrs. Virsaládze as belonging to the thirteenth or fourteenth century. During the nineteenth century, the church was enlarged and the original west wall was demolished along with its frescoes. Besides this loss, considerable damage also occured due to weather conditions. Although neither the Deesis (Fig. 3) nor the remaining six scenes of the Dodecaorton were intact, many of the single figures were well preserved before the earthquake.

The main characteristics of the style were the linear and rhythmic elements of the figures in the extant scenes as in the Annunciation (Fig. 5), the Raising of Lazarus (Fig. 7), the Crucifixion, the Anastasis and the Ascension, as well as single figures in antique garb. Moreover a lavish decoration, both painted and/or in relief, framed the compositions, adorned some of the single figures (Fig. 18) and ornamented the architecture (Fig. 2). The figures such as the Angel facing the Donors (Fig. 4) on the lower register of the north wall, the archangel Gabriel in the scene of the Annunciation on the upper register of the east wall (Fig. 5), the enthroned Deesis Christ in the conch of the apse with the Virgin and St. John the Baptist (Fig. 3) ${ }^{4}$, and the prophet Isaiah ex-

1. For Georgian art see A. T a ylor, Georgian Art and Architecture, and the related bibliography in: The Oxford Dictionary of Byzantium, I-III, New York-Oxford 1991, III, p. 841-843; N. Th ie r r y, Peintures d'Asie Mineure et de Transcaucasie au Xe et XIe siècle (Variorum Reprints), London 1977.

2. R. Mepisashvili, V. Tsintsadze, The Arts of Ancient Georgia, Leipzig 1977, London 1979. For Zemo-Krichi, ibid., p. 117-119 and plan h, figs p. 166-168 and p. 230-231. For Svaneti, ibid., p. 8, 14, 45, 117, 229, 230-231, 275; V. Beridze, G. Alibegasvili, A. Volskaya, L. Xuskivadze, The Treasures of Georgia, Milan 1983, London 1984. For Zemo-Krichi, ibid., p. and figs 71-73 and p. 90. For Svaneti, ibid., p. 6, 49, 59, 64-65, 74-78, 84-90, 101-106, and passim.

3. T. B. Virsaládze, Freskovaia rospis v cerkvi archangelov sela Zemo Krixi, Ars Georgica 6 (1963), p. 107-166 (French summary). 4. T. Velm a ns, L'image de la Deisis en Georgie, CahArch 29 (19801981), p. 47-102 and n. 3. For Zemo-Krichi, ibid., p. 69f, figs 14-16 and plan 15. For Svaneti, ibid., p. 59-92 passim, figs 3-7, 12-13, 17, 20-26, 31-37, 40; idem, La koine grecque et les régions périphériques orientales du monde byzantin, XVI. Internationaler Byzantinistenkongress, Akten 1/2, Vienna 1981, p. 677-723, figs 1-30. The Deesis theme, in the church at Zemo-Krichi, which is combined with a Cherubim and Seraphim portrayed respectively on either side of the enthroned Christ and the Prophet Isaiah confirms the inclusion of the Prophetic Vision. 
pounding his vision with his open scroll, on the north side of east wall, clearly display the lack of interest of the artist in the organic rendering of the human body. The two archangels Michael and Gabriel which are depicted on the barrel vault of the sanctuary exemplify this feature (Fig. 3).

Another characteristic is the ample drapery with thick vertical folds highlighted by vigorous convolutions which generate an impression of movement. This can be observed for example in the rendering of the himation of the Angel facing the Donors (Fig. 6), the Deesis Christ (Fig. 9), and the apostle with Christ only partially preserved in the scene of the Raising of Lazarus on the east wall (Fig. 7). These figures are in sharp contrast with the portraits of the bishops on the lower register of

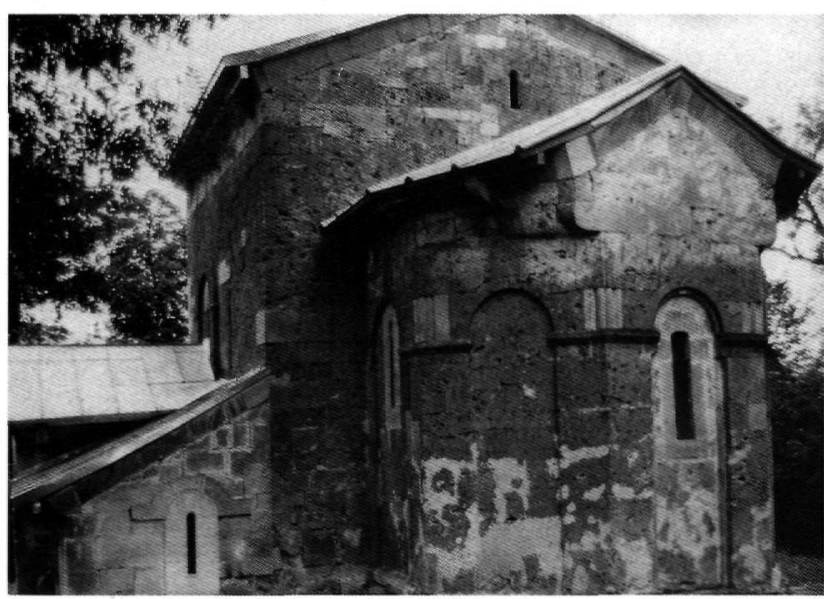

Fig. 1. Zemo-Krichi. The church of the Holy Archangels from the southeast.

the sanctuary below the enthroned Christ (Fig. 11). Their hieratic immobility is stressed by the flatness of their ornate vestments which encapsulate their tall full length figures. Lastly, four female saints and the four Donors were represented in formal costumes. The female figures in court attire were depicted in pairs on the lower register of the east wall on either side of the sanctuary; St. Barbara and St. Catherine on the left (Figs 13 and 16), St. Irene (Fig. 18) and St. Helen on the right. Excepting St. Barbara they all wore bejewelled crowns. Furthermore, the only full length figure was that of St. Catherine in imperial dress.

The dominant colours for the figures were ochre, red brown, black and grey on a blue background. The most conservative approach from the point of view of colour was reserved for the bishops, deacons and stylites, painted only in grey, ochre and brown.

The modelling of the faces was produced in ochre and olive-green with darker shades for the contours. No par-

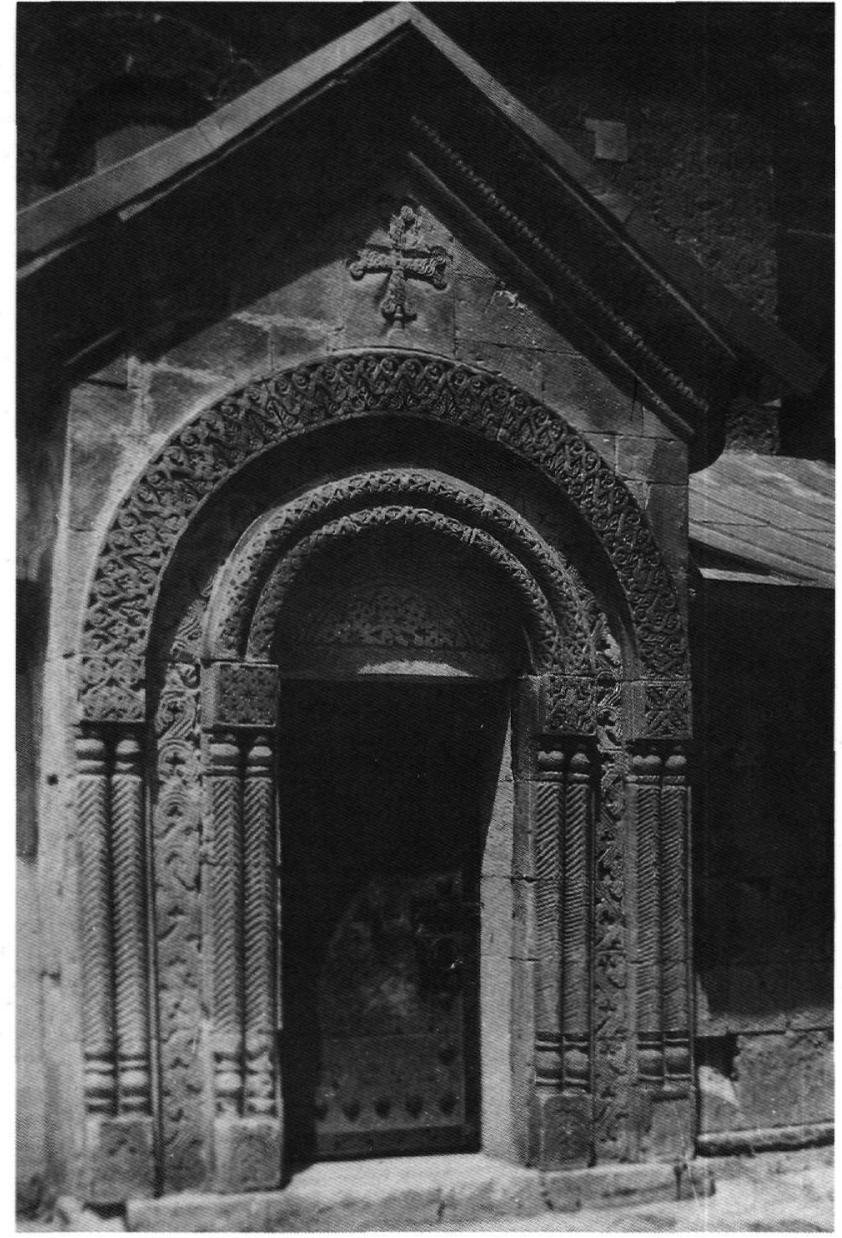

Fig. 2. The south portico.

ticular integration of colour tonalities was noticeable in the treatment of the faces. The wide cheek bones, square jaws, and the mask-like expression were made less austere by the meaningful side glances. Rouge spots were applied to the cheeks of the female saints and special emphasis was given to ornament. Brightly painted floral and vegetal motifs embellished St. Barbara's garments and adorned the adjacent female portraits (Figs 13, 16 and 18).

The stately figures of four Donors advancing towards the majestic Angel (Fig. 4) allows us to know something about the patronage of the church. Although it cannot be determined whether the first Donor held a model of the church, it can be assumed that the portraits do not represent the original ktitors but those who financed the eleventh-century mural decoration and the construction of the south portico (Fig. 2). Their tunics decorated with gold ornamentations, the cone caps and the Georgianstyle boots indentify them as feudal nobles of similar 


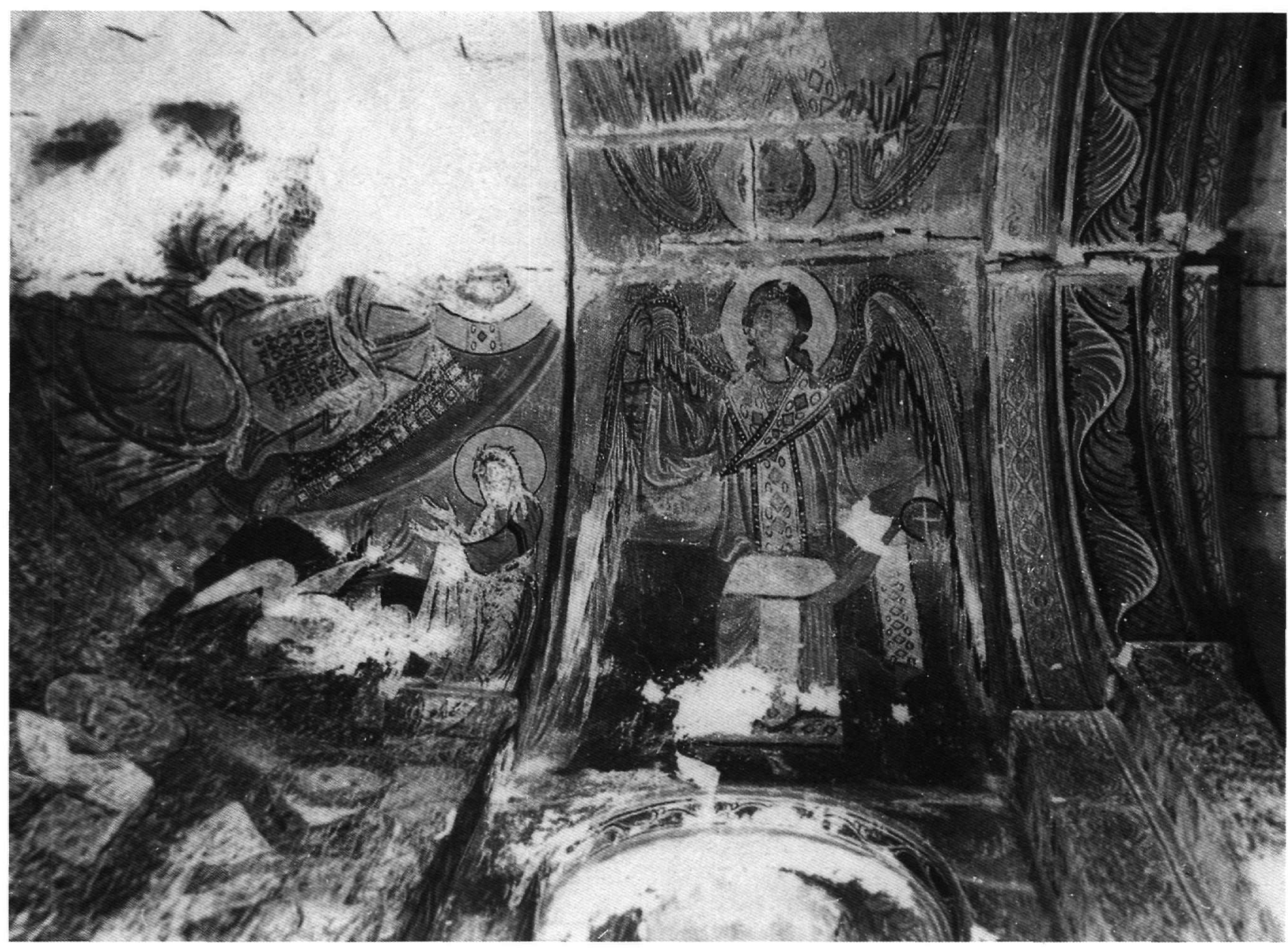

Fig. 3. The sanctuary. Barrel vault, the archangels Michael and Gabriel. Conch of the apse, the Deesis, detail: the enthroned Christ, St. John the Baptist, a Cherubim. Bottom register. The bishops, detail.

rank and probably of the same family. The Donor heading the group appears older and more richly attired than the other three. The inscriptions of their names written in magiscule letters were visible but not well enough preserved for identification.

The frescoes of Zemo-Krichi have been compared by Mrs. Virsaládze with the mural painting in the neighbouring province of Svaneti, and in particular with the frescoes of the church at Iprari, painted in 1096 by the artist Tévdoré. Although a more elaborate modelling of the figures was apparent, the expressive style of ZemoKrichi is considered to have influenced the local school of painting of Svaneti up to the mid-twelfth century. The decoration in churches such as Nakipari ca 1130 , Saint Cyricus and Julitte ca 1112, Cvirmi, and Maxvarisi ca 1140, have been cited as examples of an archaising style ${ }^{5}$.

5. For the churches of Svaneti see supra notes 2 and 4.

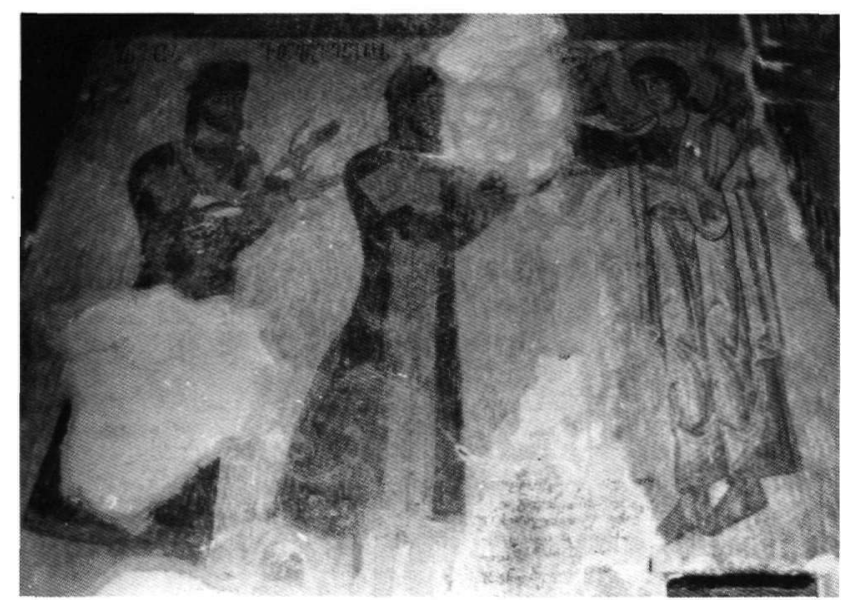

Fig. 4. North wall to the east. Bottom register. Unidentified Angel and Donors, detail. 
The survival of the Zemo-Krichi style in the later churches of this adjoining province in the Caucasian mountains, attests to its enduring influence in contrast with other Georgian provinces where the styles differ considerably. Moreover, as no other painting of the eleventh century was preserved in Rača, the subsequent development of Svaneti can be considered as a valuable source of reference.

The only frescoes of another region in Georgia which in certain instances may be compared with those of ZemoKrichi were pointed out by Mrs. Virsaládze as being those of the church of Sion at Ateni in central Georgia,

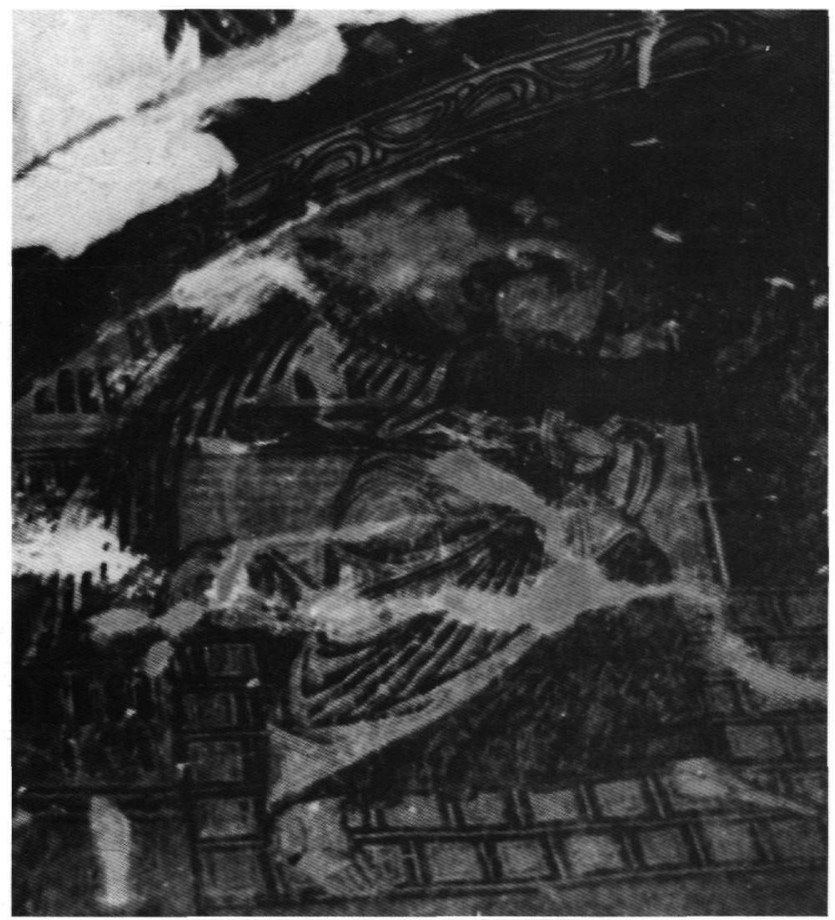

Fig. 5. East wall. Upper register. The Annunciation, detail. The archangel Gabriel.

decorated in 1080. The more sophisticated figures with a more developed awareness nevertheless still contain elements related to the earlier linear and forceful style observed in the church of the Holy Archangels. It may be noted that no regions outside Georgia have been examined in relation to the mural decorations of the eleventh and early twelfth century churches of Rača and Svaneti. The intent at present is to examine an area in southern Greece, the Mani in the province of Lakonia, whose secular medieval architecture resemble remarkably to that of the mountain villages of Svaneti and whose numerous Byzantine churches retain invaluable examples of provincial painting ${ }^{6}$. It may moreover be observed that Constantinople, as an artistic epicenter of

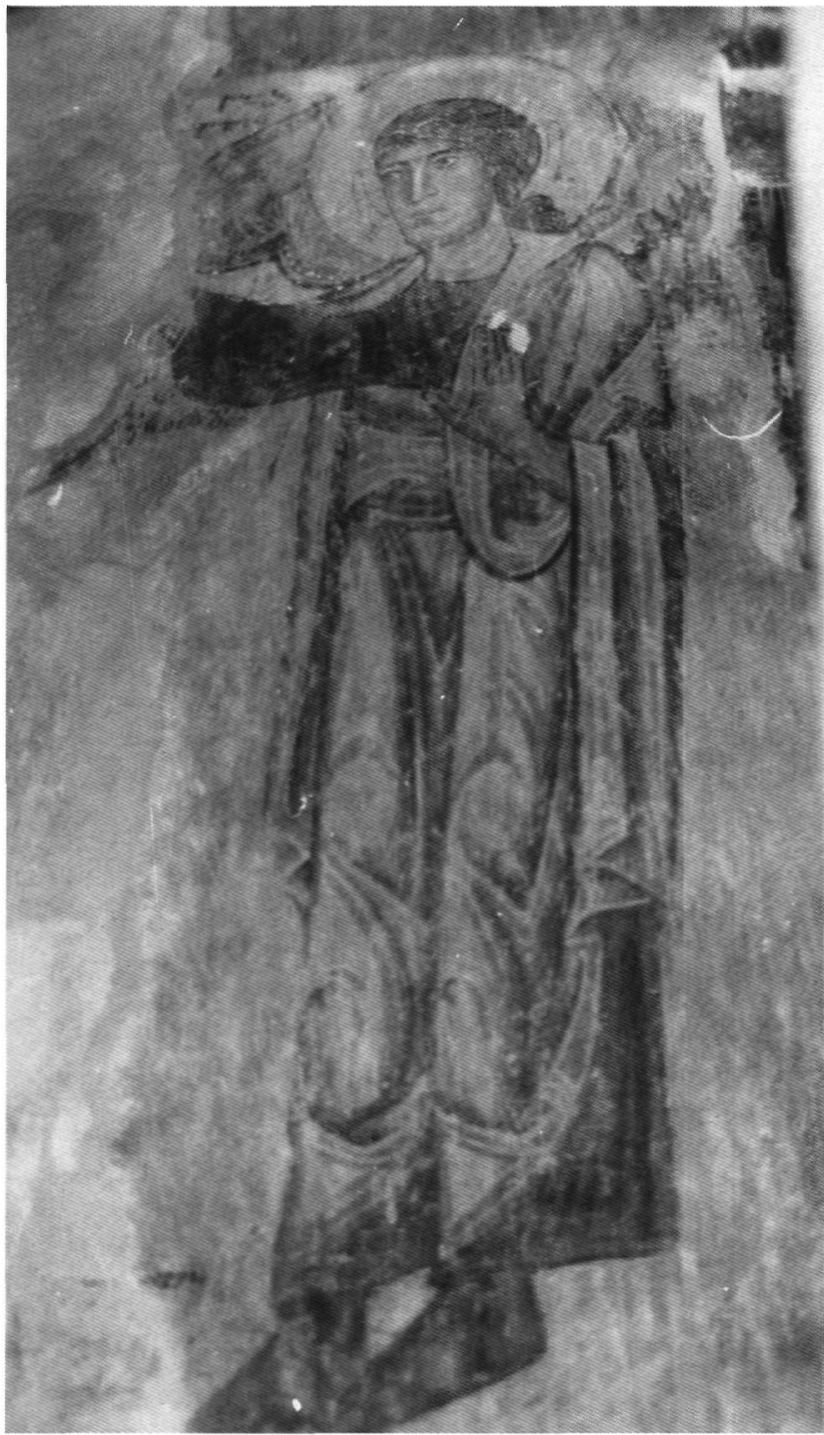

Fig. 6. North wall to the east. Bottom register. Unidentified Angel facing the Donors.

the near-eastern medieval world, was not at a further distance from the Georgian province of Rača and Svaneti than from the Mani in the southern Peloponnese.

Although excavations in the Mani have brought to light monuments from the early Christian and Iconoclast periods, it should be recalled, that the region formally entered into the political and ecclesiastical history of Byzantium as a Christian province of the Empire during the reign of Emperor Basil I, in the late ninth century? Relatively few monuments from the tenth, eleventh, and twelfth centuries are preserved compared with the considerable number of extant mural decorations of the thirteenth century and later. 
Numerous small churches were constructed along the western slopes of the mountain range which extends down the center of the Mani peninsula separating west Mani from its eastern side. Many of the monuments were built at a considerable walking distance from their respective communities. It may be presumed that most of these churches were privately built on land owned by those who financed the construction. There are however no identifiable donor portraits in these early churches. The fact that monastic churches are relatively rare strengthens the theory of private and communal ownership ${ }^{8}$.

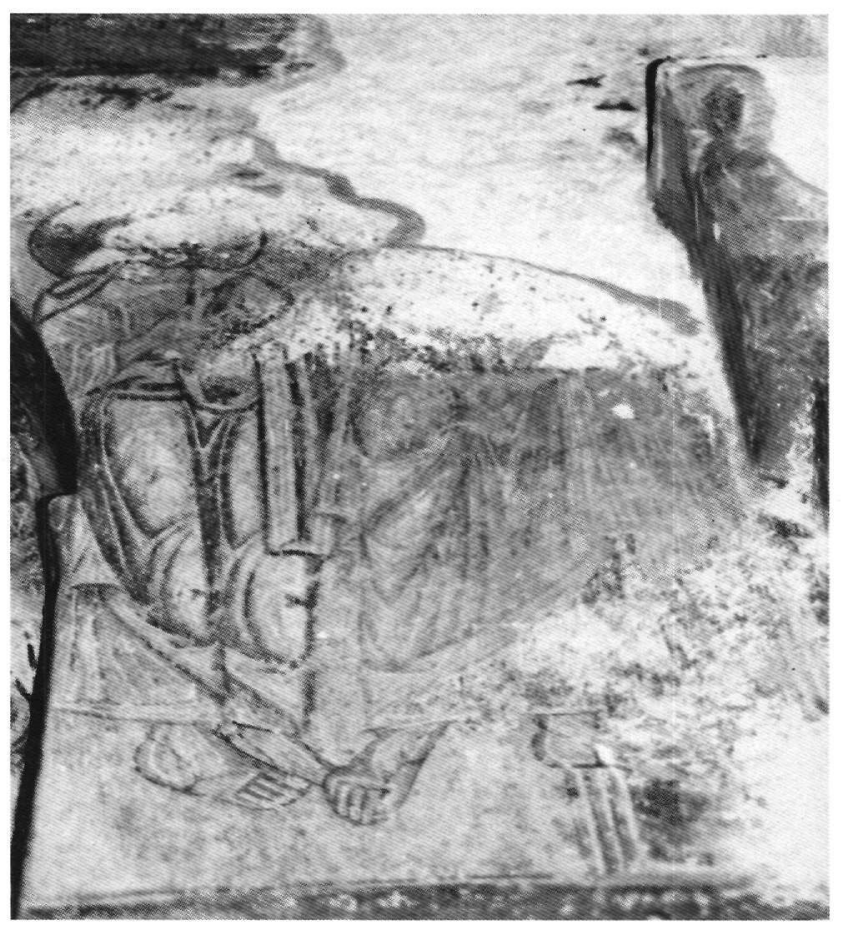

Fig. 7. East wall. Middle register. The Raising of Lazarus, detail. Christ and an apostle.

Close to three of these villages of the so-called Inner Mani, namely Boularii, Kounos, and Gardenitsa, there are three small churches dedicated respectively to Saint Panteleimon, Saint Paraskevi, and Saint Peter which can be dated to the late tenth or early eleventh century on stylistic criteria. They preserve numerous frescoes and have some characteristics in common with the painted decorations of Zemo-Krichi as well as with those in some churches of Svaneti which I had the occasion to visit. I shall however limit this present comparative study to Zemo-Krichi which is closest in date and shares in my opinion many similar stylistic features with the above-mentioned churches of the Mani.

Up to now Saint Panteleimon is the earliest known dat- ed church in the Mani which preserves its inscription. It is a small single nave barrel-vaulted edifice, at present half demolished. The eastern section retains its two apses with a three-register fresco decoration and a painted inscription dating the monument and the frescoes to $991 \mathrm{AD}$. The figures are characterized by large heads and strongly accentuated features. The eyes are particularly emphasized and the faces stark (Fig. 20). Although the paintings are naive in character and execution, they possess expressive qualities enhanced by the ornamental use of colour. These paintings serve to define the dating of the frescoes of Saint Paraskevi near

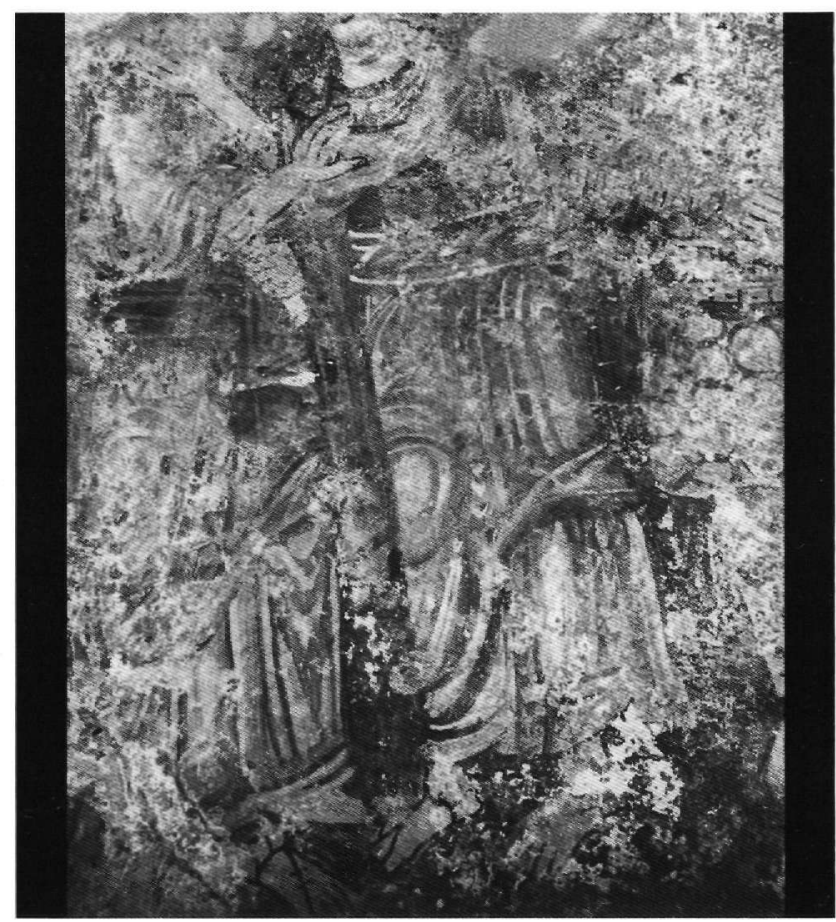

Fig. 8. Mani, Kounos. Church of Saint Paraskevi. South wall. The Betrayal of Christ, detail.

Kounos and of Saint Peter near Gardenitsa, where the bust of the archangel Michael in the apse exemplifies the style (Fig. 21) which followed after Saint Panteleimon of Boularii.

The single-nave barrel-vaulted church of Saint Paraskevi, located in the cemetery of the village of Kounos,

6. T. E. Gregory and A. Weyl Carr, "Mani", and the related bibliography in: The Oxford Dictionary of Byzantium, II, p. 12841285. For the mural decoration of churches in Mani, see esp. N. B.

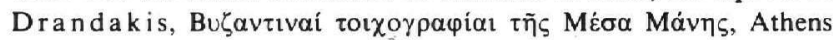
1964.

7. A. B on, Le Péloponnèse byzantin jusqu'en 1204, Paris 1951, passim.

8. D. A. Zakyth in os, Le Despotat grec de Morée, II. Vie et institutions (Variorum Reprints), London 1975, p. 4-12, 20-29, 189-192. 


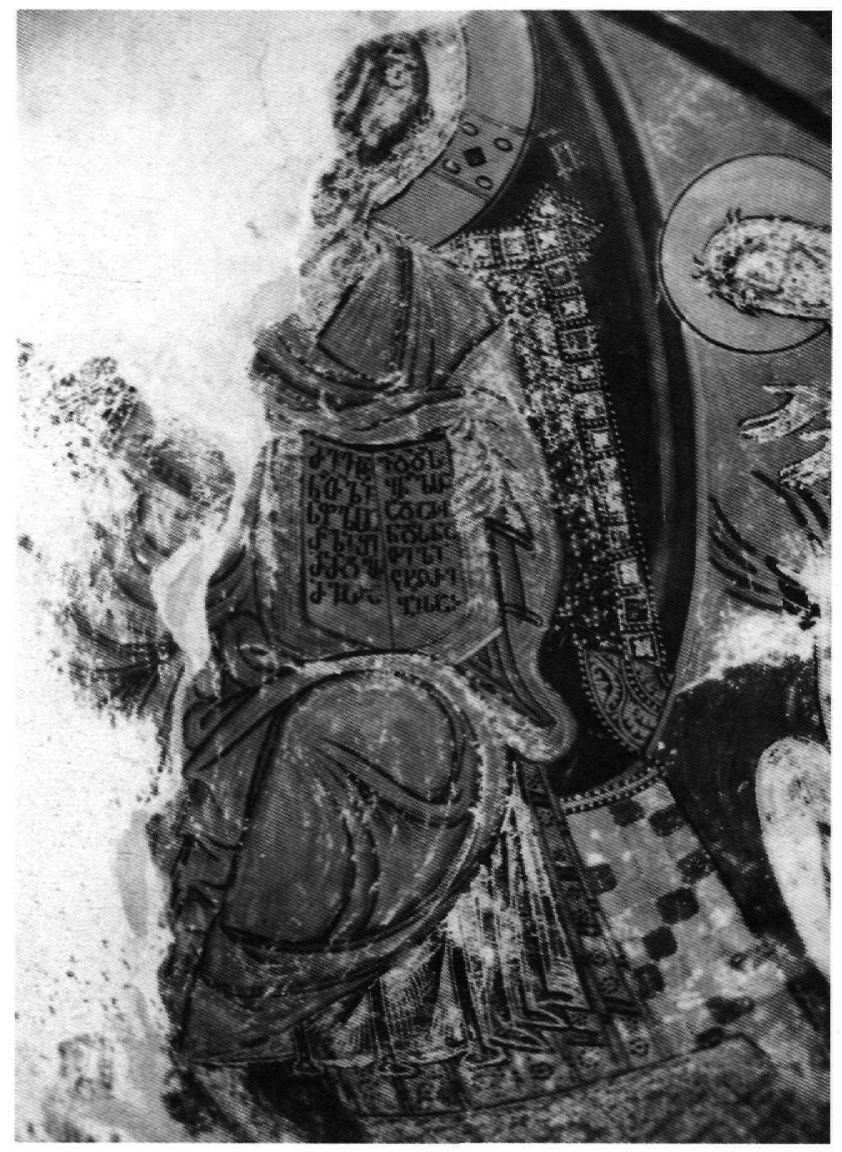

Fig. 9. Sanctuary. Conch of the apse. The enthroned Christ of the Deesis, detail.

preserves much of its painted decoration on the north and south wall, while the paintings of the eastern apse and the west wall are greatly damaged. Nikon Metanoite, the tenth-century patron Saint of the province of Lakonia, is depicted on the north wall along with St. Kyriaki who has the days of the week painted on her gown, and St. Evlavia who is standing beside her.

On the south wall, the scene of the Betrayal of Christ is partly preserved, depicting the stiff figure of Judas kissing Christ (Fig. 8). A close stylistic relationship with the fragment of the scene of the Raising of Lazarus at ZemoKrichi (Fig. 7) is apparent. In both scenes the garments are treated in a similar manner. Dark vertical lines accentuate the legs, and decorative oval patterns outline the knees in an abstract unrealistic way, thus creating a rhythmic effect that energize the otherwise static figures. This stylistic approach is particularly emphasized by the wide inverted hems which dip abruptly from the thighs to the feet; a rendering which applies to most figures clad in antique garments at the Holy Archangels and at Saint Paraskevi near Kounos (Figs 5 and 8).

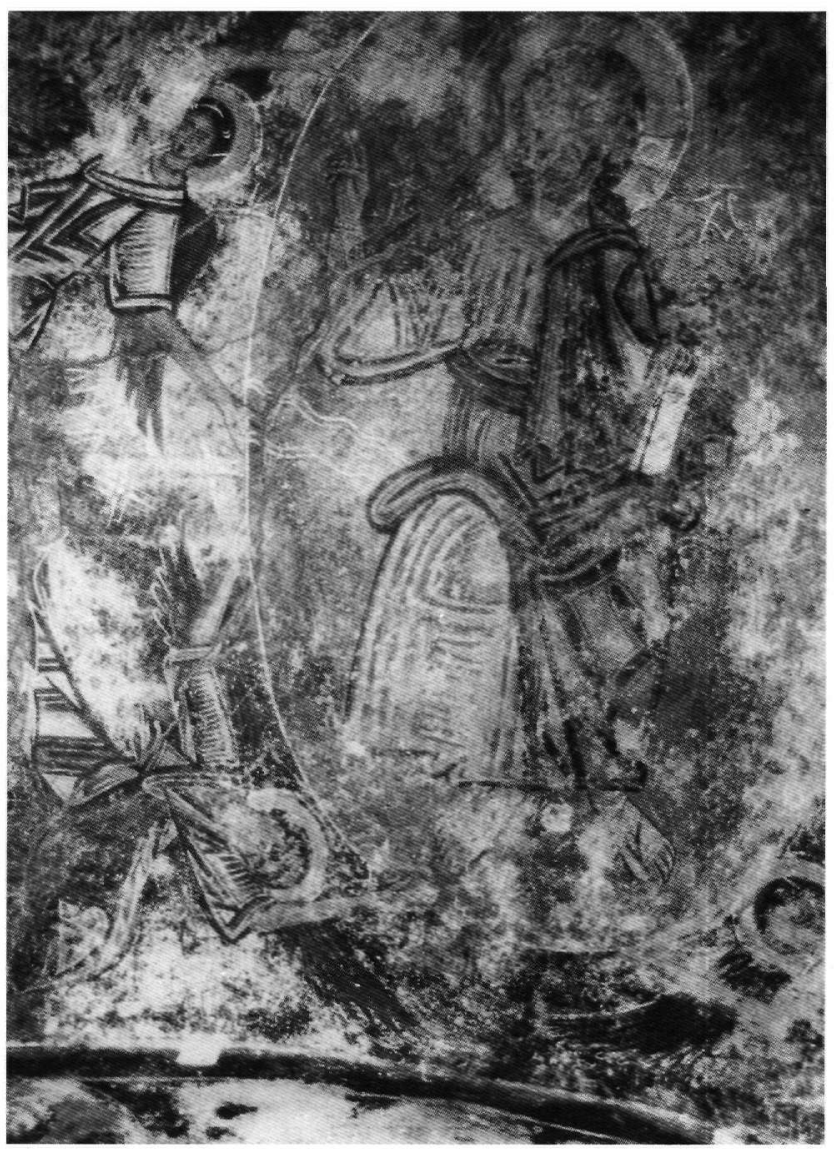

Fig. 10. Mani, Kounos. Church of Saint Paraskevi. Barrel vault of the sanctuary. The Ascension.

Among the single figures the three female saints at $\mathrm{Ze}$ mo-Krichi (Figs 13, 16, and 18) and the bishops (Fig. 11) serve for comparative purposes. St. Barbara and an unidentified female saint at Kounos (Figs 13 and 14) are portrayed respectively with wide oval faces, strong features, accentuated noses, and a particularly determined expression around the mouth. It may be observed that the more worldly look of the Georgian saints is in contrast with the impersonal stare and ecstatic look of some of these Mani saints. This latter feature could indicate either an earlier dating of the frescoes in the Kounos church or a retrospective tendency.

The depictions of St. Irene at Zemo-Krichi and at Kounos may also be mentioned in order to illustrate that the differences in their physiognomies do not detract from a common ideal of sanctity. Both are rendered with the same expressionless countenance that typifies early eleventh-century portraiture (Figs 18 and 19). On the other hand, the personalized portrait of an unidentified bishop at Saint Paraskevi, Kounos, typifies the close physiognomic traits shared by the prelates of these two 


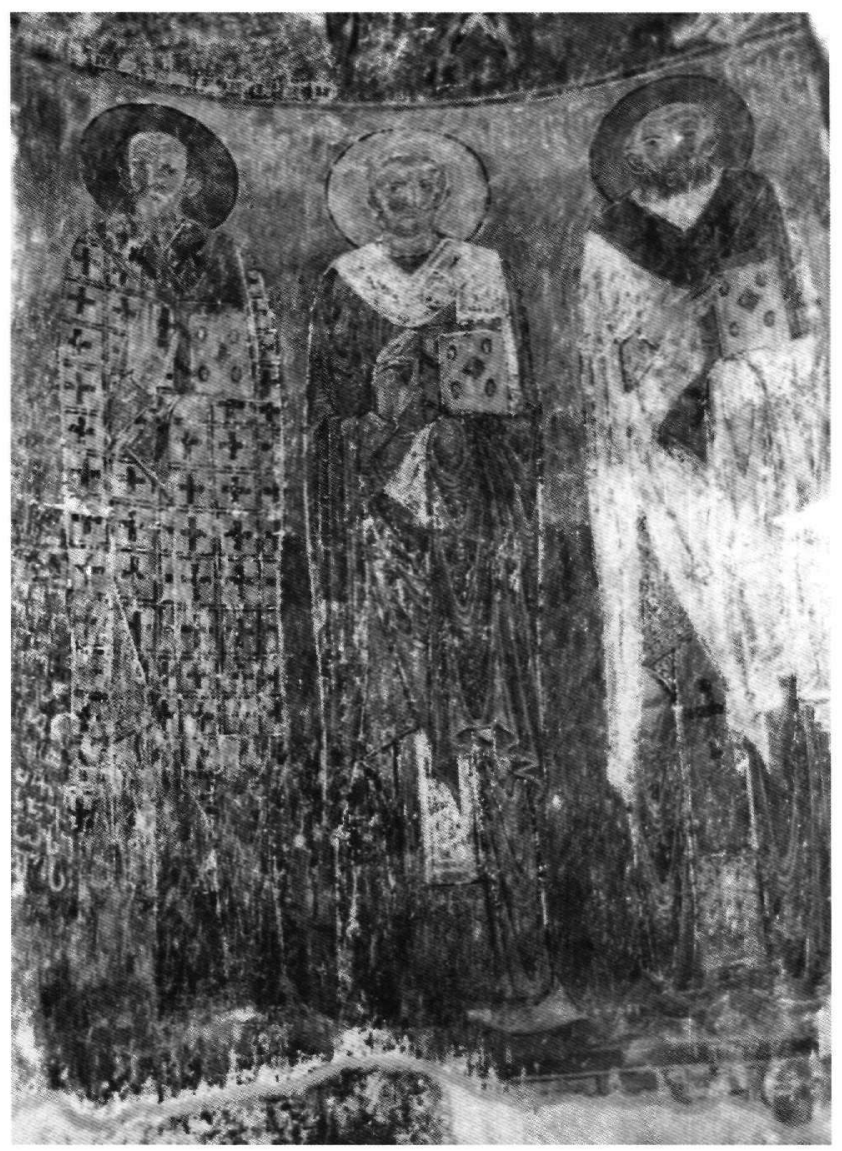

Fig. II. Sanctuary. East wall. Bishops.

churches of Rača and Mani respectively (Figs 22 and 23). Not far from the church of Saint Paraskevi at Kounos, outside the village of Gardenitsa, is the church of Saint Peter, a single-nave, barrel-vaulted monument possessing a double eastern apse.

The bishops in the church of the Holy Archangels and the ones preserved at the church of Saint Peter of Gardenitsa are examples of similar expressions of severity and awareness (Figs 11 and 12). In both churches, these prelates also lend themselves for comparison as regards their hieratic bearing and the wooden quality of their stance. Their garments emphasize their rigid frontality. Moreover, the stern look of the bishops at Zemo-Krichi and the ascetic countenance of those at Gardenitsa conform to the same provincial conventions of iconography and style. Painted with an elementary modelling, they share the same mood. Although the style of painting is less dynamic than at Zemo-Krichi, and the figures are smaller due to the restricted size of the church, they have in common the flat linear approach for the rendering of the figures and similar decorative and colour

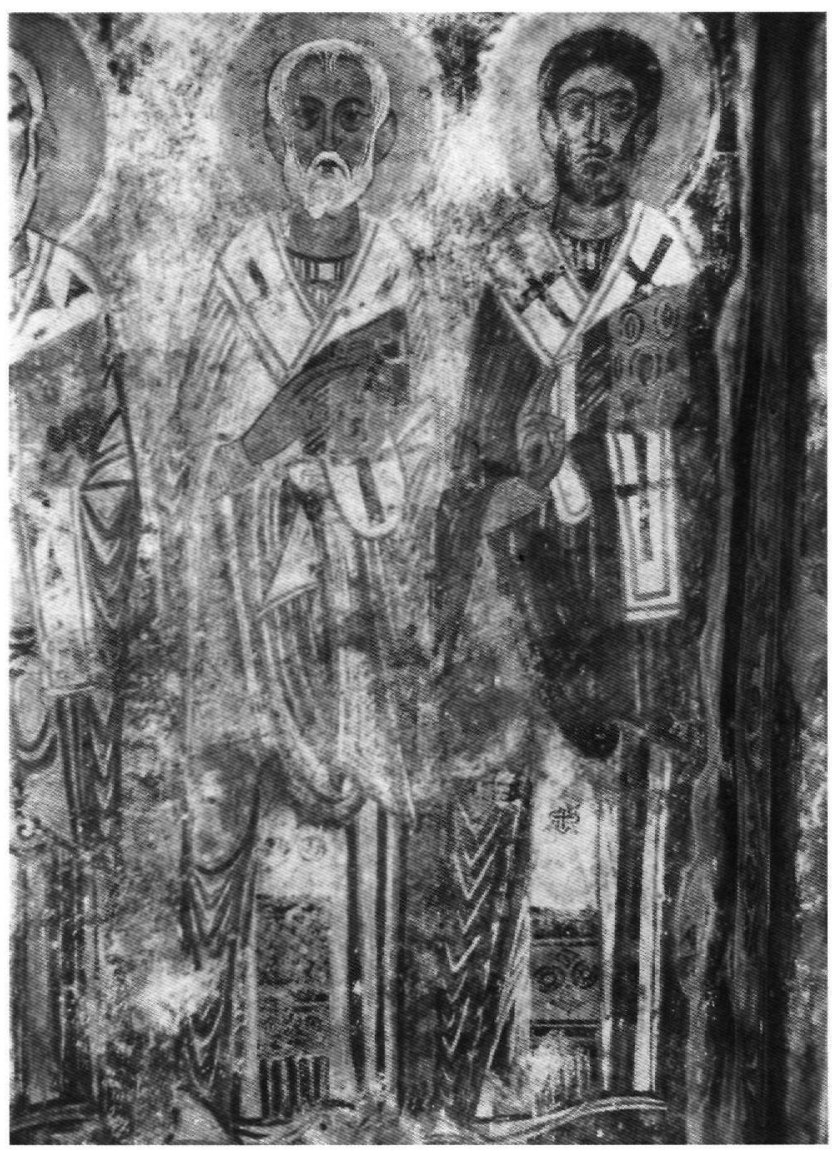

Fig. I2. Mani, Gardenitsa. Church of Saint Peter. North wall. Bishops.

qualities. The Deesis Christ in the eastern apse at ZemoKrichi and Christ in the Ascension scene on the barrel vault of the sanctuary of Saint Paraskevi, Kounos serve likewise to illustrate these points (Figs 9 and 10). The archangel Michael on the barrel vault of the sanctuary at Zemo-Krichi and the archangel Michael on the north wall at Gardenitsa (Figs 24 and 25), can also be likened. Both figures are richly attired, and display highly embellished wings. The Zemo-Krichi angel however, depicted with a low manneristic waistline, is further removed from the classical norms of the organic rendering of the human body. His Mani counterpart nevertheless is equally two-dimensional with the wide flat loros covering most of his body.

Among the female saints, St. Barbara and St. Catherine at Zemo-Krichi (Figs 13 and 16) and St. Paraskevi and St. Helen at Gardenitsa (Figs 13 and 17), are representative examples of female portraiture in both churches. The half length figures of Barbara and Paraskevi share a lack of integrated modelling for the faces with vivid rouge spots on the cheeks and flesh tones which do not 


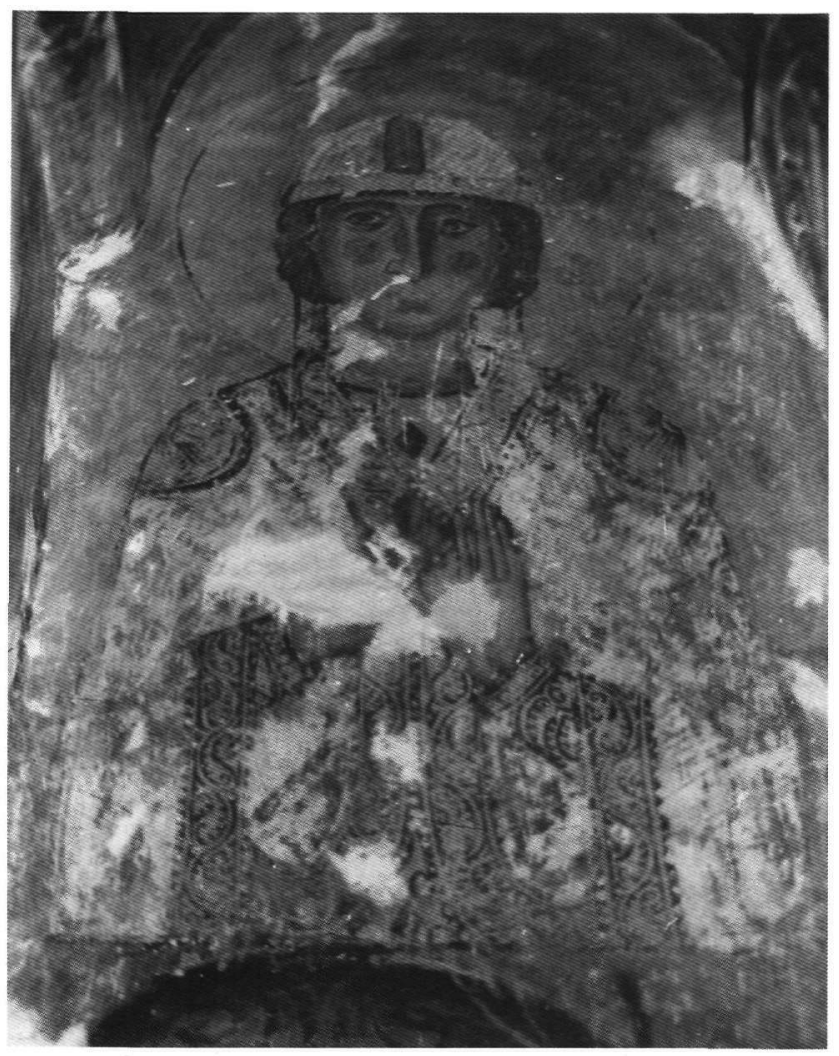

Fig. 13. East wall to the north. Bottom register. St. Barbara.

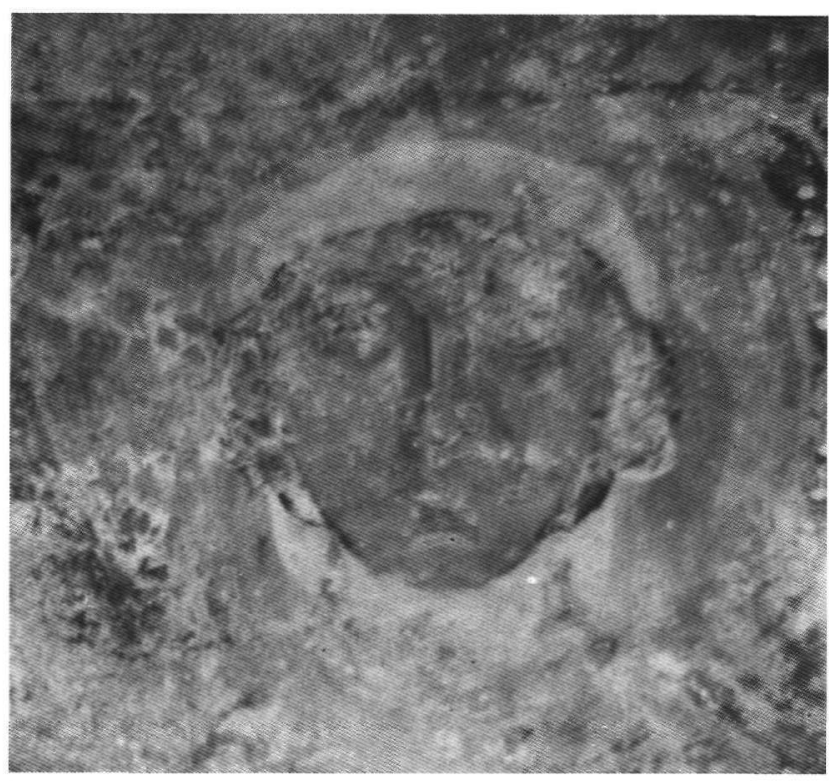

Fig. I4. Mani, Kounos. Church of Saint Paraskevi. North wall. Unidentified saint.

Fig. 15. Mani, Gardenitsa. Church of Saint Peter. Sanctuary. East conch to the north. St. Paraskevi.

Fig. 16. East wall to the north. Bottom register. St. Catherine. blend. Numerous decorative details enhance their appearance; as for instance, the schematic curls and the ornate cap of St. Barbara, and the white frills on the black hood as well as the enormous halo adorned with pearls of St. Paraskevi (Figs 13 and 15).

The two full length female figures are richly attired. St. Catherine and St. Helen (Figs 16 and 17) standing frontally, are both depicted profusely adorned with precious stones and pearls which is a handy decorative substitute for the lack of modelling. The authentic Byzantine iconography for the imperial dress of an empress is adhered to more closely at Zemo-Krichi where St. Catherine's thorakion is clearly depicted resembling that of the Empress Irene, whose enamel and silver gilt portrait is preserved on the Pala d'Oro in the Cathedral of Saint Mark, Venice. A similar thorakion can be discerned on the eleventh-century Zoe panel of the south gallery of Agia Sofia at Constantinople?

An iconographic detail may also be noted in connection with their crowns. Mrs. Virsaládze elaborated on the type of crown worn by St. Catherine which conforms to

9. J. Beckwith, The Art of Constantinople, London 1968, p. 110f., fig. 137. Irene was the wife of Alexios I Comnenos (1081-1118). E. Coche de La Ferté, L'art de Byzance, Paris 1981, pl. 71.

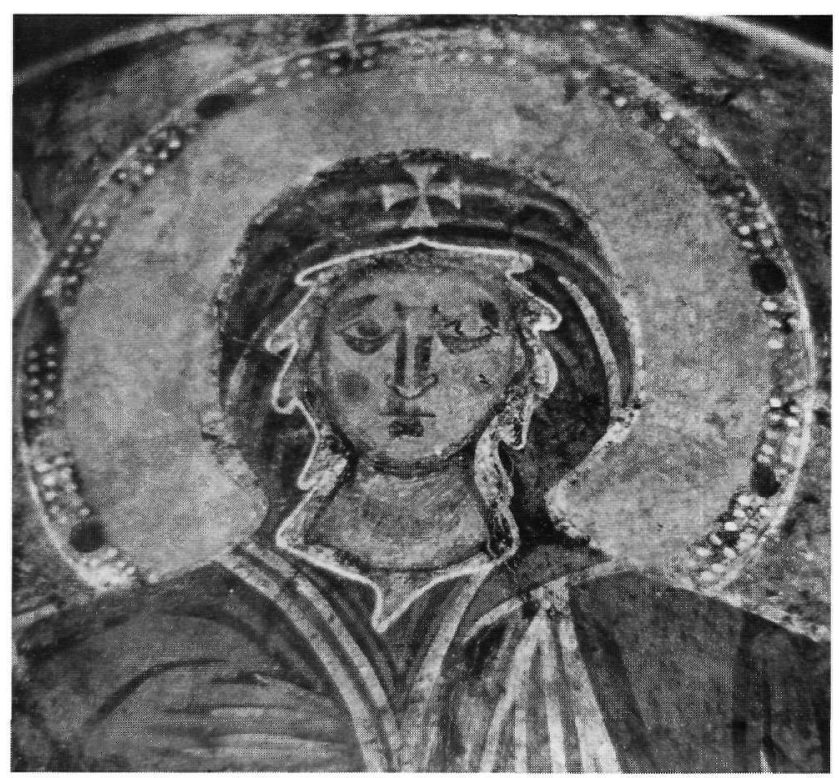

Fig. 17. Mani, Gardenitsa. Church of Saint Peter. North wall. St. Helen and St. Constantine.

Fig. 18. East wall to the south. Bottom register. St. Irene.

Fig. 19. Mani, Kounos. Church of Saint Paraskevi. South wall. St. Irene. 
THE FRESCOES OF THE CHURCH OF THE HOLY ARCHANGELS AT ZEMO-KRICHI (GEORGIA)

16

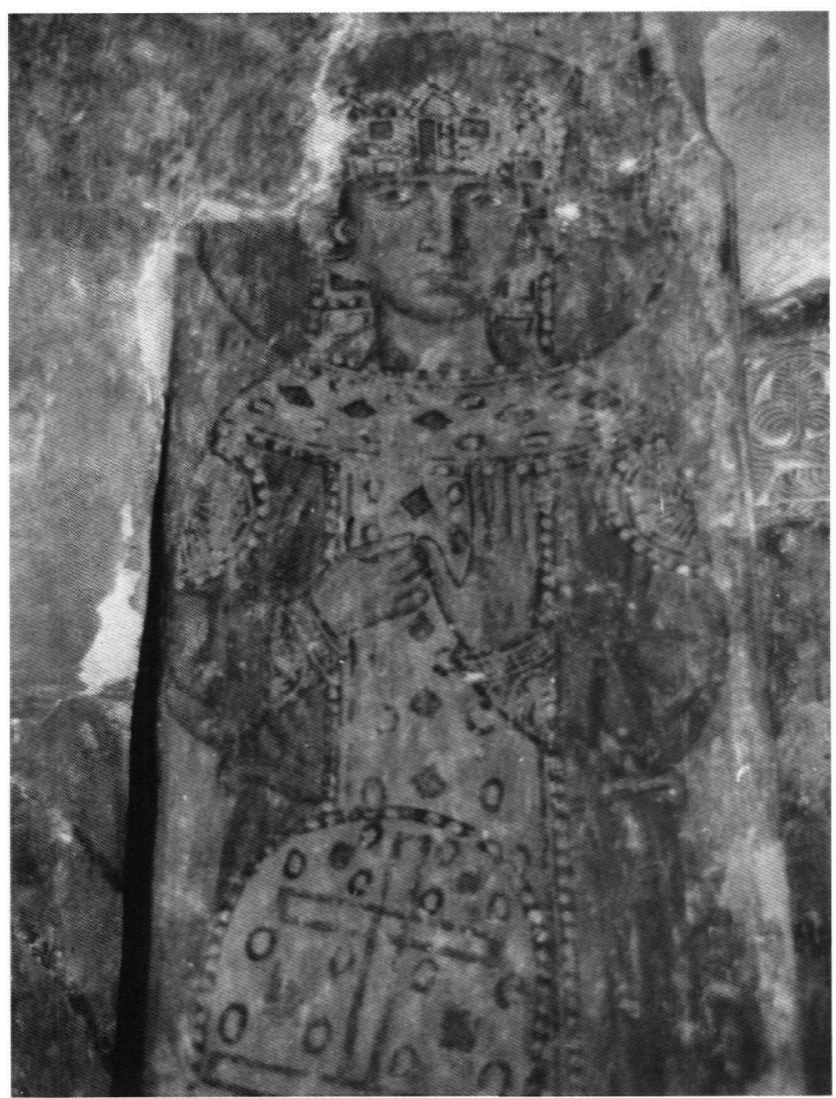

18

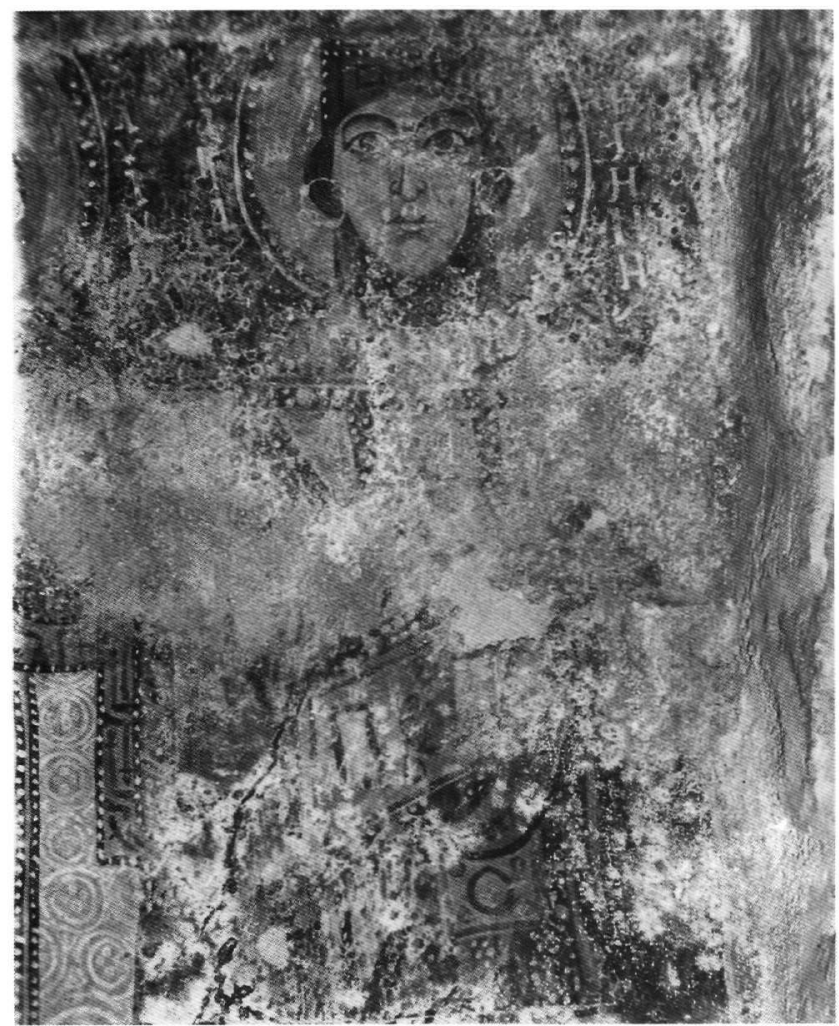

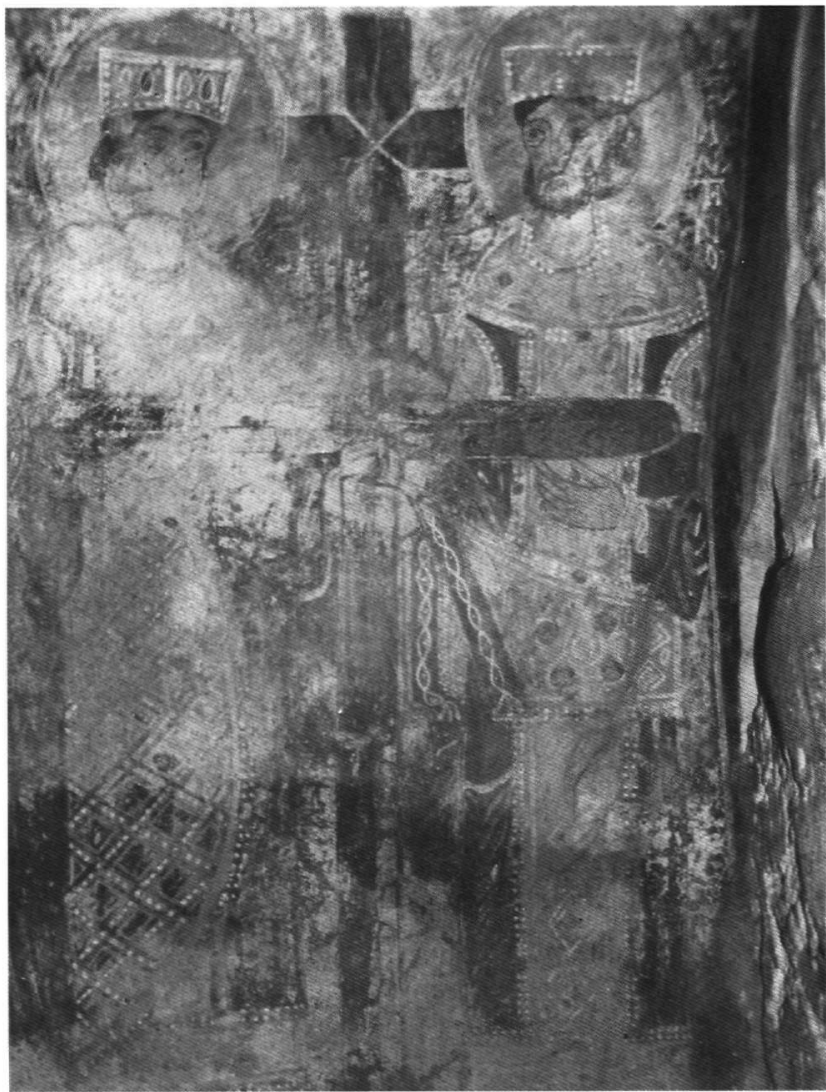

17

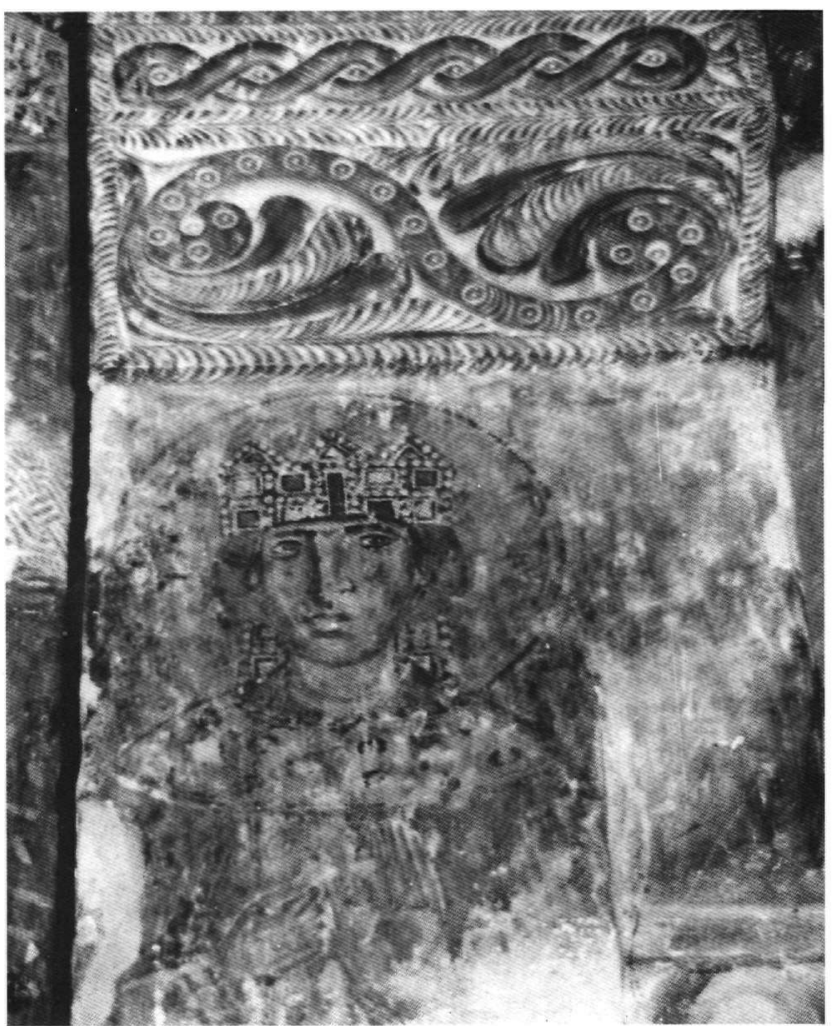


the imperial Byzantine stemma. At Gardenitsa, St. Helen's is a simplified archaic variant of the Byzantine crown (Fig. 17). It is apparent that the Rača artist was better informed than his Mani colleague as to imperial iconography.

Mention should be made of the colours at Gardenitsa which are better preserved than at the church of Kounos. There is a preference for bright hues as at Zemo-

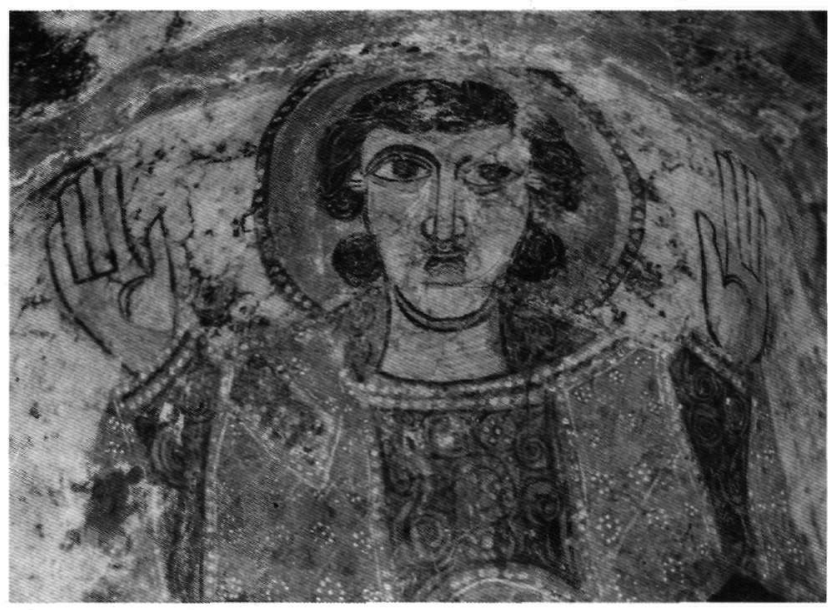

Fig. 20. Mani, Boularii. Church of Saint Panteleimon. Conch of east apse to the south. Unidentified saint.

Fig. 22. Sanctuary. East apse to the south. Bottom register. Unidentified bishop.

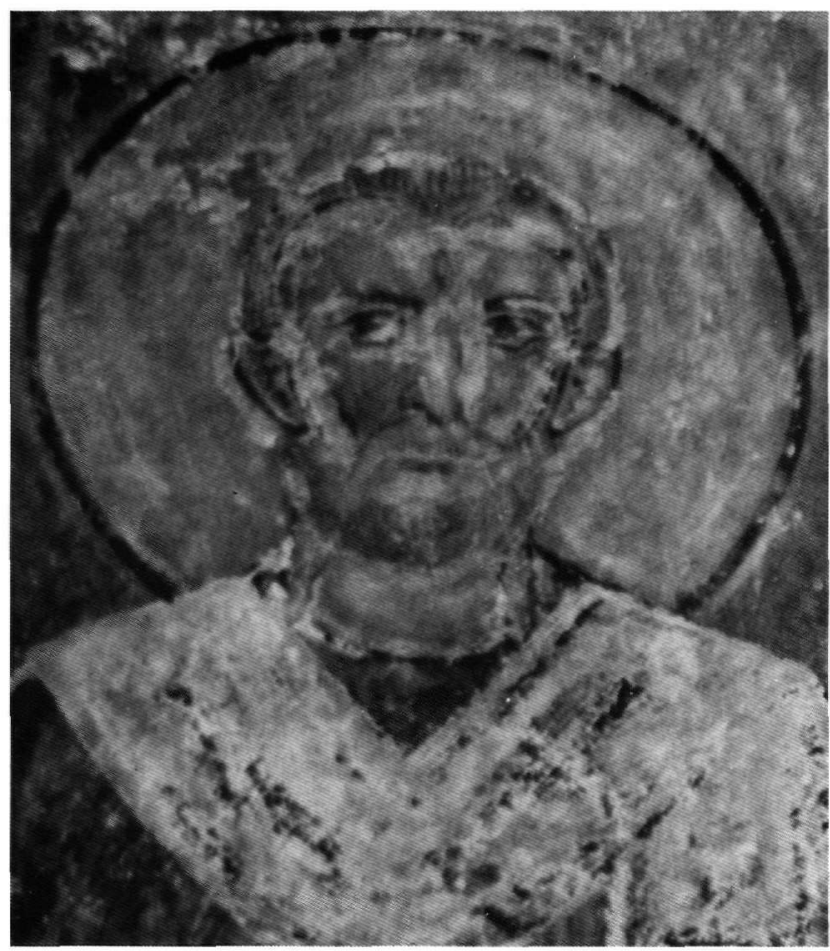

Krichi, particularly red, blue, and ochre. Unlike the Rača church however, the brown and grey colours are lacking and the red is of one tonality. Blue is employed for the background as at the Holy Archangels where they adhered to a Byzantine tradition which was often substituted by white backgrounds in Georgia, as for example in the church at Ateni.

Before concluding, two questions may be raised:

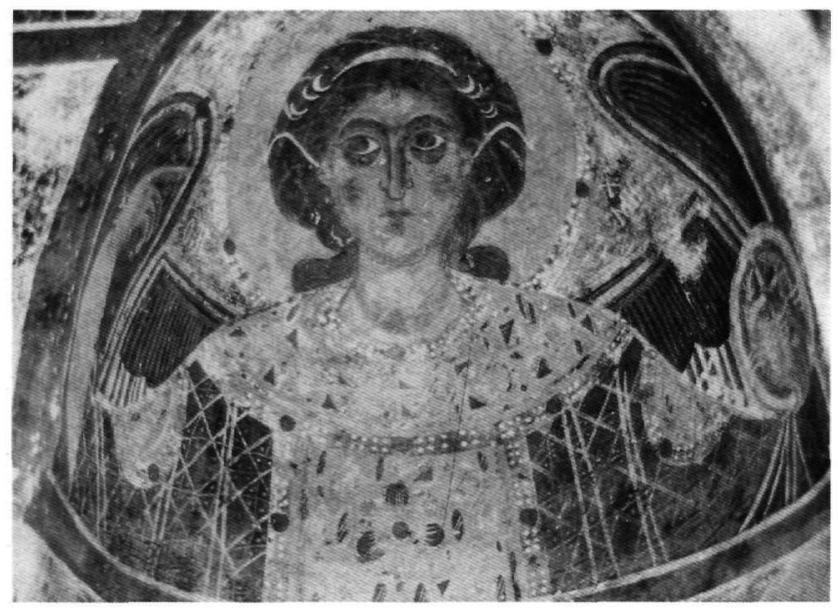

Fig. 21. Mani, Gardenitsa. Church of Saint Peter. Conch of east apse to the south. The archangel Michael.

Fig. 23. Mani, Kounos. Church of Saint Paraskevi. Unidentified bishop.

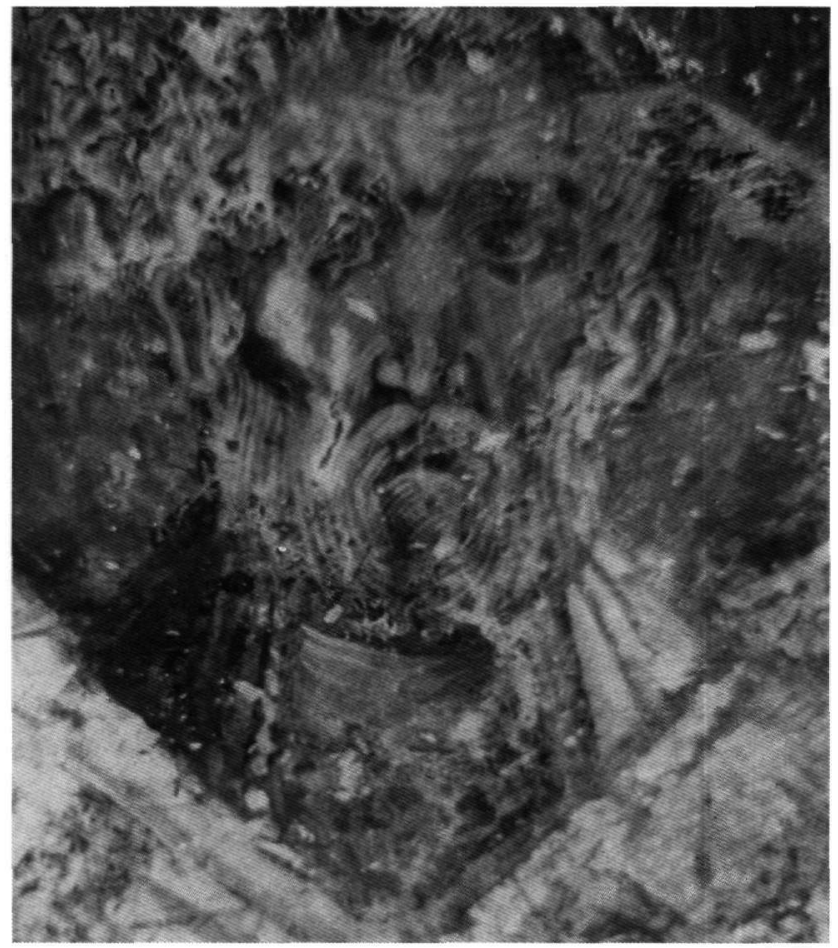




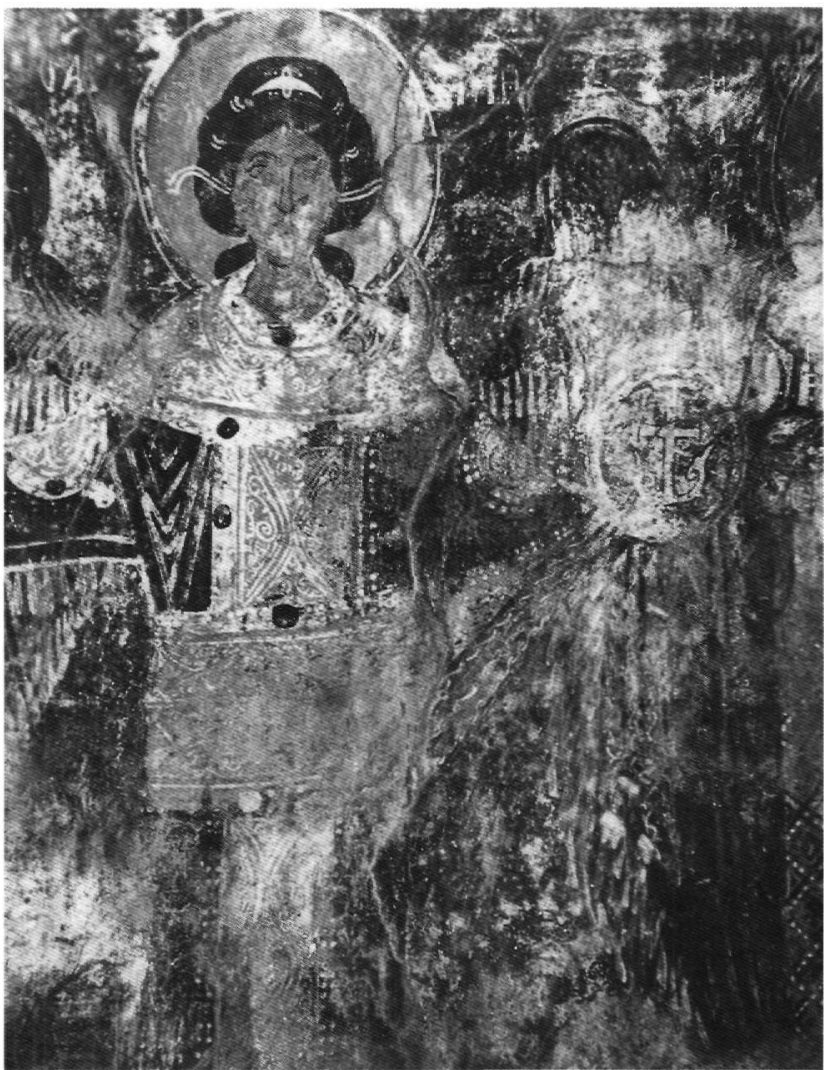

Fig. 24. Sanctuary. Barrel vault. South half. The archangel Michael.

First, is there a common denominator by the eleventh century which embodies the various stylistic currents of provincial painting?

Secondly, did major monuments in the provinces executed by artists from important artistic centers, influence the minor monuments of local provincial painters? As regards the first question, the comparisons made between a church in Rača and those of Mani geographically so far apart reveal four basic features of the mural decorations that is shared in common, irrespective of the distinctive character of each monument.

In both regions the figures are depicted in a highly decorative linear style and their rendering gives an impression of false plasticity. The manipulation of the drapery expresses movement in an inorganic manner. The Deesis at Rača and the Ascension scene of Kounos illustrate this point (Figs 9 and 10).

The handling of the human figure does not follow classical norms. Figures are either overly tall with large hands and feet as at Zero-Krichi and Boularii (Figs 5, 7, and 20) or small and crowded together as in the Mani churches of Kounos and Gardenitsa (Fig. 12). Moreover, the figures are stiff and their movements angular

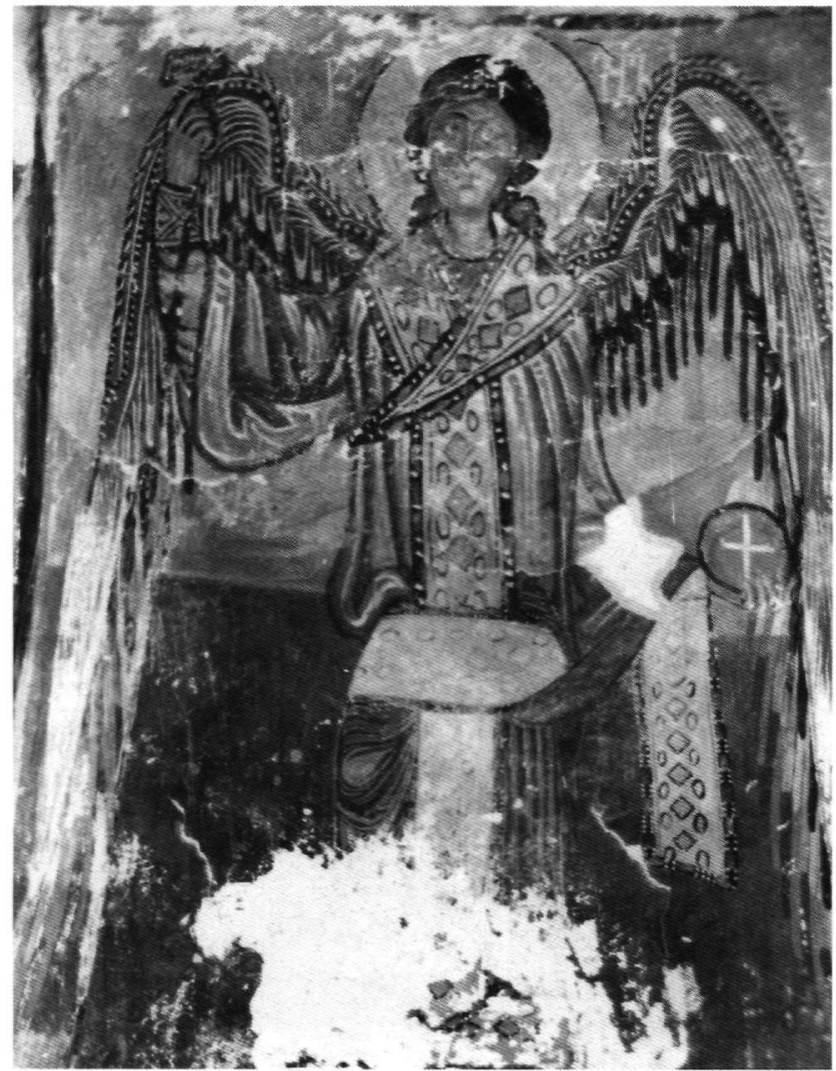

Fig. 25. Mani, Gardenitsa. Church of Saint Peter. North wall. The archangel Michael.

thus emphasising their anticlassical tendencies. In most cases the contrapostal pose is totally absent.

In both regions, colour and chiaroscuro effects are not employed to achieve a three-dimensional presentation of the figures. Instead, they serve to accentuate their two-dimensional appearance in a more forceful manner. Lastly, the predelection for horror vacui, which is observable especially in the scenes, may be also noted in the abundant ornamentation.

An answer may be advanced for the second question regarding the influence of major monuments upon minor ones in the provinces.

In the region of Phokis near Delphi, a most ambitious monument, whose iconography and style constitute one of the leading models of early eleventh-century artistic expression, is the katholikon of the monastery of Osios Loukas ${ }^{10}$. It can be safely considered as an example of a major metropolitan product executed in the provinces. Moreover, it could hardly have gone unnoticed by pro-

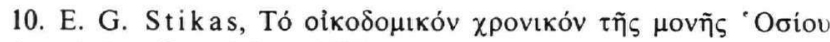

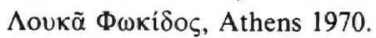


vincial artists of a wide periphery, in view of the mobility of their profession and the models they required.

The mosaics and frescoes of Osios Loukas rendered in a highly accomplished style embody most of the above mentioned features evident in the modest artistic production displayed in small contemporary churches. The Kounos and Gardenitsa examples clearly suggest this connection. A case in point are the bishops of Osios Loukas executed in mosaic and those painted at Gardenitsa. They share much the same colour tonalities, facial expressions, and the proportions executed in a two-dimensional conservative tradition (Fig. 12) ${ }^{11}$.

A parallel stylistic rendering also applies at Zemo-Krichi when two of the bishops (Fig. 11) are juxtaposed with the painted portraits of an unindentified bishop and that of St. Menas depicted on the north side of the northwest chapel at Osios Loukas ${ }^{12}$. Furthermore, the facial types of the Zemo-Krichi archangels in the sanctuary cannot be overlooked (Figs 3 and 24), when compared to the mosaic medallions of St. John in the narthex of Osios Loukas and of the archangel Raphael on the south vault ${ }^{13}$. Within this context the Gardenitsa archangel in the eastern apse to the south (Fig. 21), may be juxtaposed with the two painted representations of Imperial Archangels in the northwest chapel of the katholikon ${ }^{14}$ of the monastery.

Lastly, it may be noted that red haloes have been included at Zemo-Krichi as at Osios Loukas. The portrait of St. Catherine at Zemo-Krichi (Fig. 16) and the medallion portrait of St. John the Theologian in the crypt of Osios Loukas, exemplify this feature ${ }^{15}$.

As regards iconography, the modern version of Christ in the mosaic scene of the Anastasis at Osios Loukas ${ }^{16}$ inspired by the classical features of the Macedonian Renaissance, is one of the earliest extant renderings of its kind in mural decorations of this period. This new aspect of the Anastasis was also to be seen at Zemo-Krichi. In both churches, Christ was represented frontally. His forceful frontal counterpoise is in contrast to his previous traditional side-stance as depicted in the mosaic scene of the Anastasis at Nea Moni, Chios ca 10401070 , where the earlier iconography was still retained ${ }^{17}$. The affinities between the distant Rača monument and Osios Loukas imply a common source issuing from a dynamic artistic center. It may be proposed that the capital of Byzantium during the eleventh century was the fountainhead of the artistic forms which spread to the regions under its religious influence. The relationship between the art of Osios Loukas to that of the Mani and Rača paintings, seems to indicate that comparing distant monuments does not necessarily involve geographical distance but the common east Christian artis- tic language which as a highly expressive spiritual force knew no frontiers ${ }^{18}$.

In this respect what seems to call for attention is the connection between the basic practices of eleventh-century art. As for the differences in quality these largely depended on the Donors whose affluence and influence as well as their rank, played an important role in the execution of the artistic project. They could either engage artists from a metropolitan center as seems to be the case of Osios Loukas, or, as at Zemo-Krichi and the above-mentioned Mani churches, they could choose among the talented provincial artists to decorate their churches $^{19}$.

11. Ibid., pl. 61

12. T. Chatzidakis-Bacharas, Les peintures murales de Hosios Loukas. Les chapelles occidentales, Athens 1982, pls 6 and 7.

13. Stikas, op.cit., pls $19 \alpha$ and $64 \alpha$.

14. Chatzidakis-Bacharas, op.cit., pls 29-32.

15. C. L. Connor, Art and Miracles in Medieval Byzantium, Princeton 1991, pl. 1 .

16. Stikas, op.cit., pl. 4. See also Coche de La Ferté, op.cit., pl. 73.

17. D. Mouriki, The Mosaics of Nea Moni on Chios, Athens 1985 , I-II, p. 133-139 and pls 48-57, 180-189. A. D. Kart son is, Anastasis. The Making of an Image', Princeton 1986, esp. p. 213-218, figs 81-83. 18. D. Mouriki, The Formative Role of Byzantine Art on the Artistic Style of the Cultural Neighbors of Byzantium: Reflections of Constantinopolitan Styles in Georgian Monumental Painting, XVI. Internationaler Byzantinistenkongress, Akten 1/2, Vienna 1981, p. 725757, figs 1-52. A. P. Kazhdan and A. Whart on Epstein, Change in Byzantine Culture in the Eleventh and Twelfth Centuries, Berkeley, Los Angeles, London 1985, p. 140-144, 170-172, 215-216, 232-233. A. J. Wharton, Art of Empire, Painting and Architecture of the Byzantine Periphery, University Park and London 1988, p. 5-12.

19. For painters and patrons of the Middle Byzantine period see: R. Cormack, Painting after Iconoclasm, in: Iconoclasm (ed. A. Bryer and J. Herrin), Birmingham 1977, p. 160-163; ide m, The Byzantine Eye: Studies in Art and Patronage, passim (Variorum Reprints), London 1989; A. Wharton Epstein, Tokali Kilise, Tenth-Century Metropolitan Art in Byzantine Cappadocia, DOS 22, Washington D.C. 1986 , p. 33-39. The author acknowledges the dearth of photographic material illustrating this article, due to the limitations established for this volume. 